Mirko S T A R Č E V I Ć (University of Ljubljana)

mirko.starcevic@gmail.com

\title{
GERARD MANLEY HOPKINS AND THE ECOLOGICAL BALANCE OF WILDNESS
}

Accepted: 25 July 2019

UDK 821.111.09-1Hopkins, G.M.

82.09:502/504

In the nineteenth century, the swing of anthropocentric forces wrought profoundly deleterious changes upon the face of the natural environment. Witnessing these metamorphic processes at work was Gerard Manley Hopkins, whose unique sensibility found the despoilment of nature by human hand no less than extremely dispiriting. Against a backdrop of the vanishing beauty, Hopkins fervidly engaged with the transforming world in his ecopoetical ruminations. He was not the first poet of ecological dissent, for during the Romantic period John Clare had poignantly expressed the anguish at what had then been the incipient stages of nature being disrobed of its inherent singularity. Being quite familiar with Clare's ecopoetical meditations, the Jesuit poet was able to further elaborate upon Clare's vision, while proving successful in presciently observing the discrepancies between wilderness as a cultural construct and a wildness whose emphasis upon the appreciation of the global through the local corresponds closely to the present-day awareness concerning the fragility of ecosystems. Most vividly and extensively, Hopkins explores the dyad of wildness and wilderness in poems like "Inversnaid," "Duns Scotus' Oxford," and "Binsey Poplars," wherein he truly establishes himself as one of the essential forerunners of modern ecological science.

Keywords: Gerard Manley Hopkins, ecopoetics, wildness, wilderness, ecology

Hopkins swung in suspension between elected (fullness of absence) and involuntary (absence of fullness) silence. Delving into silence should not be misjudged as escapism or withdrawal, for by virtue of lighting upon the silent mode of being-in-the-world, one is not rendered impermeable to the world but unfurled unto it. Silence can be kindred to bounteous solitude as opposed to loneliness, whose scourge grows in shadowy prominence when 
silence is used as a tool of manipulation for accomplishing overpowering and malignant ends, or is generated by unwieldy conditions. The pastoral vocation designed to mend broken souls and offer comfort to impecunious multitudes is a task daunting enough on its own merits without the requisite moments of long silent contemplations continually being discontinued by the ferment of the outer world. Solitude thus being superseded by loneliness, the quality and character of services must perforce suffer. Yet in spite of adverse circumstances which left Hopkins' aims cast adrift and remaining numerous, a puzzling ambivalence prevails in Hopkins as he was able to perform some of his best pastoral work at Bedford Leigh, a town architecturally all too barren and quelled for an individual smitten with endless landscapes, although its atmosphere was brightened by "the charming and cheering heartiness of these Lancashire Catholics" (Hopkins 1955: 97). On the whole, however, his migratory existence persisted in gnawing at him, and although still being safely ensconced within the sky-embracing towers of Oxford, he, as early as 1864, composed a Tennysonian lyric in which he forebodingly encapsulates his future peace-desiring supplications to be afforded a haven, "Where no storms come, / Where the green swell is in 180 the havens dumb, / And out of the swing of the sea" (Hopkins 2009: 27).

The Victorian epoch represented a time of swift technological and industrial advancements and many a time Hopkins, in places to which he was sent, struggled mightily to find God. Industrial towers were oozing ominously ill-coloured smoke, the streets were unruly, housing properties oftentimes despondently rickety, and people generally appeared forlorn. Brief excursions into the countryside grew ever briefer with his advancing age, not owing to the abatement in his desire to frequent the parks or undertake forays deeper into the countryside, but primarily due to the insurmountable burden of the daily tasks he had to perform in an environment that stood in preponderant disagreement with his frail stature.

His poems, journals, and correspondence betray an underlying angst by mirroring the marrow of nature which in many cases was crushed and fragmented. A scrupulous observer of nature, Hopkins used his infinitely precise eye to descry, and his searing pen to document, the damage done to nature's inscape, but, stress we must, he harboured no intrinsic antipathy against urban areas as such. Not infrequently does he compliment the cultural and communal value of cities, and it is precisely this ambivalence in Hopkins' juxtaposition of nature and urban environment - with both ruled by wildness - which is so powerfully enticing to ponder. The task of this paper will, for this reason, be to examine, by applying an ecocritical 
analysis, the effects of the rapidly transmogrifying environment upon nature and, as logically follows, Hopkins himself. Teaching us to regard our global biosphere as highly fragile, his careful observations and warnings should not go unheeded. They speak to us of the environmental challenges we are faced with today and they implicitly entreat us to possibly readjust our mental compasses and strive toward a more unifying approach in the attempts to reverse some of the trends which largely already appear irreversible.

Before we truly begin with the analysis, a couple of preliminary points about the critical framework that we shall employ in the essay need to be illumined. Since our discussion will deal with the eco-poetical awakening present in Hopkins' work and thought, we deem it to be the best course of action to highlight the nuances of Hopkins' non-linear approach to the subject matter of ecological devastation, an approach which re-begot the post-Romantic spark of animating within the human populace a sense of environmental consciousness. The purpose of an ecocritical reading is to address, if not redress, the failure of a multitude of critical theories to tackle the growing ecological problems and the manner in which these problems are laid out and yet overlooked when analysed within the context of different literary forms. One of the goals of this paper is to demonstrate that Hopkins often went beyond the merely aesthetic norms of a literary work or thought. In Song of the Earth, Jonathan Bate states that ecocriticism's "true importance may be more phenomenological than political" (75), which does not necessarily mean that ecocriticism in conjunction with the phenomenological paradigm is apolitical, nor that it is a pure abstraction of the form characteristic of the post-structuralist theories which the ecocritical paradigm wishes to critically distance itself from. Rather, it is pre-political, for it teaches the mind to perceive nature in its irreducible isness without failing to progress to a crucial stage of monitoring the way that learned introspections might inform its proper and unrushed political application. To convey the sense of significance with which Hopkins thought the notion of dwelling with nature, we shall then, within the bounds of an ecocritical approach, trace not only that which (the what) Hopkins found most treasurable in nature but also the way (the how) in which he regarded nature's preserved and despoiled signifiers and the fashion in which he was both aesthetically and morally affected by their respective states. Coming up with highly original and phenomenologically underpinned explanations of the nature of human perception, Hopkins saw it as one of his objectives to make our judgements less estranged to the idea of our unobtrusively dwelling with and among nature's inscapes. The poet was averse to providing answers 
imbued with pragmatic finality, so that any attempt to reduce Hopkins' work to a set of utilitarian standards is bound to prove otiose. Although Hopkins' power of observation was uncannily incisive, the full extent of his scientific knowledge remains somewhat dim. What is clear, however, is his deep fascination with all natural phenomena. One such example of his unfathomable enthrallment with the natural world can be discerned from the letters he wrote for Nature, the then leading science journal, in which, in an empirically meticulous fashion, he noted down the transfigurations in colour-schemes, shapes, and atmospheric canvases, as a result of the volcanic eruptions at the island of Krakatoa. ${ }^{1}$ Like in his other work, these letters bespeak a genuine care with which Hopkins instressed the varying forms of natural phenomena along with their inherent frailty and susceptibility to human spoliation. The goal of our ecocritical reading will, therefore, be to highlight the eco-poetical features in Hopkins' thought, to show, as Bate writes, "in what respects, [say], a poem may be a making (Greek poiesis) of the dwelling-place ... 'the home or place of dwelling"' (75), and finally to render his poems and writings transparent to the notions of what dwelling with nature could and does mean for us and our posterity, and to hopefully 182 recognize them as advantageous to the aims of undoing the popular need to subject nature's isness to the unreflected upon ideas of progress.

The echoes and beams of the Dual Revolution lent Victorian Britain a solid ideational and physical framework of what at first seemed a rather reticent and with time accelerating growth of urban settlements. No single account can hope to deliver the definitive judgement on the incalculable nuances of Victorian urbanization, but one should nonetheless aspire to purvey the immense variability and myriad complexions of a Victorian town, its conceptual exemplar, along with the local countryside. Before we can adequately tackle Hopkins' relationship to the shifting landscape, a momentary pause is expedient in order for us to consider some fundamental propositions regarding the supposedly paradoxical features that the Victorian town embodied, and the extent to which these features possess the ability

${ }^{1}$ See Nature, Vols XXVII (16 Nov 1882), XXIX (15 Nov 1883; 3 Jan 1884), and XXX (30 Oct 1884). 
to inform and enhance our comprehension of the vicissitudes rural life and nature at large underwent with the advent and then unmitigated budding of urban life.

The functional line dividing a village from a town was, during the incipient stages of urbanization, still well pronounced in a village and its rural setting, acting as host to the dawning industrial ventures. As Dyos states, the modern industrial nuclei, in the initial developmental phases, were still glued together, and with the nearby villages, they first started forming "to a large extent outside the existing towns and moved into them only when [for instance] water-power gave way to steam" with its commercial dynamics in a piecemeal fashion being converted "from country-dominated town to town-dominated country" (1982: 8). Villages within towns gradually proved a not uncommon phenomenon, for changed circumstances impelled people to reestablish and reforge their associations and identities, a process which did not entail the wholesale shedding of old habits, traditional customs, and means of securing sustenance. The farm colonies enwrapped within town limits abounded in the ambience innate to half-agricultural societies, which for instance resulted in streets bestrewn with "cow-stalls, sheep-folds, pig-sties above and below the ground, in and out of dwellings, on and off the streets" (Dyos 1982: 9).

As the bulkier segments of formerly rural communities chose to divorce themselves from their age-old customs, the liberty to retain a semblance of rusticity even within the seemingly unbounded and depersonalized enclaves of bricks rendered the transition to the urban world less potholed. Moreover, newer climates ushered in freshly-minted opportunities, and if many were willing and indeed forced to safeguard strong attachments to tradition, some desired to investigate unchartered seas. Social mobility, however, was sometimes hindered by society's disapproval of the formation of potentially disruptive assemblies, which were mostly set up as "small pockets" (Dyos 1982: 9) by those sharing a similar social and economic status. The opposing forces of the new social reality gave birth to the many differing experiences of the citizenship. Some individuals who felt oppressed by the previously highly personalized relationships of rustic communities, witnessed that encumbrance gradually melt away. Towns and later cities, on the other hand, could prove labyrinthine with streets numberless and masses inestimable, which made room for much-coveted sanctuary from eyes thirsty for calumny and prying. But the danger that solitude would eventually slip into loneliness had always remained real. The legions of faces and eyes could dazzle and at any time invoke a sense of unworthiness 
while the assumed antagonisms of the past at times lost colour and unveiled a more amiable visage. A yearning for the rarefied air of nature and a more intimate encounter with the Other could always rematerialize. In many an individual it did. The sense of loneliness could easily tumble into devastation and could be further exacerbated by the sinister implications of the slums which Hopkins in Liverpool experienced first-hand and Dickens in Sketches by Boz called a congeries of "wretched houses with broken windows patched with rags and papers" (1868: 176). The extreme switchbacks in one's disposition towards the industrialized and urbanized world had partly to do with the rapidly inflowing population accompanying the increasing birth rate and immigration, both of which were the cause and corollary of an economic and industrial upsurge, alongside which the ambitions of city planers and industrialists were constantly reevaluated; in an analogous way, the needs and living conditions of the general populace were being altered in accordance with those ambitions. During the 1850s, for example, "the last of the handloom weavers" (Hobsbawm 1975: 246) in the Lancashire area were swallowed by the still tiny but expanding factory system. The hammer of progress was thundering through the land, and if the impact

184 of it within the cities was fairly ambivalent, it sealed an indelibly marring imprint upon the areas transcending the municipal borders.

The nascent days of the nineteenth century (before progress gathered its irresistible momentum) and the infamous land enclosures - with their inception in the twelfth century and their peak in the Victorian era implicitly paint a vivid picture of this process. Tracts of pastures, grasslands, dislodged and smaller plots of arable fields, normally owned and cultivated by a number of individual owners belonging to cohesive groups - under the auspices of wide-reaching farming whose genesis was concomitant with agricultural advancements - were fenced off, merged, and passed into sole ownership. The cost of land being reshaped, in many instances eclipsing familiarity, was prohibitively high. Poorly managed pastures which could be unconducive to sound economic prosperity was an argument most commonly regurgitated in favour of enclosures, but as Arthur McEvoy acknowledges, the co-owners of the commons met "twice a year at manor court to plan production for the coming months" (1987: 299), thus seizing personal initiative to keep their land soundly organized. Besides the removal of the sense of intrinsic motivation in crop production, the newfangled work system cut across the lifeline of camaraderie which had burgeoned when farmers had occasionally, in free associations, cultivated the land. The individually-based work system, a not uncommon component of the 
pre-enclosure Acts time, had also brought with it a generous measure of freedom and efficiency in comparison to the output produced by the more randomly set-up groups of farmers later on, particularly when the groups exhibited apathy and propensities for deviant behaviour.

The displacement brought to pass in the wake of the Enclosure Acts was made manifest by the impending landscape disfigurement. In his poem "The Mores," John Clare, a poet whose native village Helpston had its heaths, fields, and forests enclosed in a brief span of years from 1809 to 1820 , engenders a pang of anguish which climaxed to the fore when "inclosure came and trampled on the grave / of labour rights and left the poor a slave" (1966: 188). The free movement of cattle was constricted, their inherent nature henceforth vigorously subdued, the splendidly frolicsome springs of brooks and rivers were diverted and turned into ponds, trees stormily felled, the woods cleared and were carved into private gardens. The foot which had found solace roaming among the verdant plants and leafy branches now in vain sought the homely columns of trees and descried the sign which leaped "up to notice "no road here"" (190). The eyes were met by the vacuous stare of the dimming skies and imprisoned in unwonted conditions of pleasantness broken apart as enclosures "changed the face of the land" (Bate 2004: 106). Once the seizure of the freedom crowning the silent movements of winds in the trees and the grass had been accomplished, his poetic proclivities were undermined or - as Jonathan Bate, his major biographer, suggests - that in the world of enclosure "his poetic freedom was reined in" (75), a not insignificant assumption as it foreshadows Clare's mind turning astray and his subsequent confinement in an asylum in 1837.

E. P. Thompson, in Customs in Common, viewed John Clare as "a poet of ecological protest: he was not writing about man here and nature there, but lamenting a threatened equilibrium in which both were involved" (1993: 180). In this sense he was a precursor to literary figures such as Lord Alfred Tennyson, John Ruskin, William Morris, and primarily Hopkins, the focus of our discussion. The dual nature of loss which Thompson alludes to indicates the balancing act between the Romantic sublime and the post-Romantic ethos of natural sustainability, the companionship of which underlies "the pragmatism central to social ecology" (Parnham 2010: 27). Hopkins and Clare bewailed the taming of heather, bramble, furze, and dewy trails, but their imaginative sway is always bound to the natural milieu they regard as homespun and thence inexhaustible. Yet their jeremiad was not commensurate with a preservationist credo; their howl did not overstep the boundary of that which is immediately present within 
the world they esteemed as unfaltering. A poet needs not reach the distant beyonds to uplift the imaginative torrents. The paths he or she rambles on are manifold, "full of pleasant scenes," and then when the seeds of the natural music depart to sleep, the time arrives to "wander home / and oer the beautys we have met to muse" (Clare 1966: 183). Seeking otherness, the poet can find it in the unenclosed identity of a garden, ordinary trees, and shrubs. Neither does nature hinge on the remoteness to inspire, nor does it have to be terror-evoking and baleful to cause the senses to thrill. The craggy precipices of the Alpine ridge can contemporaneously give meaning to life and accent the realness of mutability, but so can the moaning trees swaying in the high winds. Wildlife is omnipresent and even those living outside the culturally appropriated term of wilderness partake in the lessons that nature never fails to showcase. The Romantics sometimes quested for the "troubled pleasure" (Wordsworth 2008: 161) in the outer reaches of civilized horizons. The apparent and patterned benevolence of nature close to home functioned as the mainstay of imaginative indifference. Seeing humanity as the culprit of the disorganized balance of the natural world, they escaped to the realms they helped recreate. They unwittingly spread the assumed 186 malaise of humankind, its artificialities and perils, to the very bosom of the wilderness they wished to retain unblemished. Wilderness does enchant and ensnare and those who dare explore but not imprudently push beyond its external limits should not suffer societal condemnation but should be encouraged to concede that the pursuit of the savage laws of nature is replete with cultural archetypes and, as William Cronon writes in his influential essay "The Trouble with Wilderness," that "there is nothing natural about the concept of wilderness" (1996: 79). Paradoxically, humanized wilderness as a cultural myth becomes the shrine of pantheistic pilgrimages, while the new-old world, rife with bricks, continues to reek of insolent disregard.

The dualism of setting more densely populated areas against the humanless topoi of wilderness upsets the balance between human and nonhuman nature. The preservation of wilderness at the expense of inhabited regions causes the wasting of the latter to accrue and march towards the very world of wilderness that environmentalists wish to protect. As much as the Romantics fathered the enshrinement of the natural sublime, they also articulated the profound universal concerns that far transcend the preservationist exultation of the unadulterated outback where human traces are in short supply. Wordsworth, in his sonnet "Composed upon Westminster Bridge," presents a more socially engaging poetics of ecology that would, to a considerable extent, infuse Hopkins' standard of care for 
nature's inscape. Elevated gratitude is born in the presence of the morning sun which never did "more beautifully steep / In his first splendour, valley, rock, or hill" and was attainable only "in the smokeless air" (2008: 136), devoid of furnace-generated black smoke. A popular Arcadian disconnect was overturned by the Romantics and steered back toward the purposeful caveat that the tendency of energy to "become disordered and dissipate" (Parnham 2010:235) requires for the most disruptive force of the ecosystem, modern humanity, to curb his/her ambitions so as to let nature convert entropic disruptions into an efficient and sustainable use of energy.

In "Inversnaid" Hopkins imagines the natural world impaled by the shards of ignorance and he envisions the deleterious impact on life by the permanently scarred environment:

What would the world be, once bereft

Of Wet and Wildness? Let them be left,

$O$ let them be left, wildness and wet;

Long live the weed and the wilderness yet. (2009: 153)

In these lines Hopkins makes the traverse away from the cultural appropriations of wilderness towards a more ecologically efficient perception of the environment. But in order for the traverse to be uncovered, we must first analyze those parts of the first draft of "Inversnaid" which Hopkins sent to Bridges in 1879 , two years prior to completing the poem:

Something, if I cd. only seize it, on the decline of wild nature, beginning somehow like this-

$\mathrm{O}$ where is it, the wilderness,

The wildness of the wilderness?

Where is it, the wilderness?

and ending-

And wander in the wilderness;

In the weedy wilderness,

Wander in the wilderness. (1955: 73-74)

Hopkins introduces the concept of wildness which he juxtaposes to wilderness. In his seminal paper, Cronon expatiates on the proposed distinction, stressing omnipresence of wildness by stating that wildness 
"(as opposed to wilderness) can be found anywhere" (1996: 89). In other words, wildness, which is everywhere, subsumes wilderness. A lone tree encrusted on some far-flung moorland is a kin either to a tree planted in the most congested street of a megalopolis or to a grove of trees embellishing a riverbank snaking its way through the quiet outskirts of a small town, in that they all carry the selfhood of treeness; or as Cronon astutely propounds, that "trees stand apart from us" and "share our common world" (88). A felled tree is derobed of its own thisness, regardless of its geographical context. It was in 1879, almost a year into his curacy at St. Aloysius Church, when Hopkins came across the gaping emptiness upon the banks of the River Thames once inhabited by a train of poplar trees whose demise had been ordered by pitiless railway architects. Hopkins, who "forsook the romantic notion of wilderness" (Parnham 2010: 191), but adopted and enlarged upon the romantic vision of ecological sustainability, also grounded his artistic credo on Ruskin's belief that "art should be made, not by learning from general ideas or words, but by looking at natural objects" (White 1992: 75). Looking at Minute Particulars rather than reconstituting their essence is an indispensable mode of approaching nature which converges with the 188 acknowledgement that nature surrounding both human and non-human ecosystems is "in some ultimate sense ... wild" (Cronon 1996: 89).

To return to "Inversnaid," the of-phrase in "the wildness of the wilderness" expressed in the first draft of the poem clearly implies the non-synonymous nature of the two concepts. This ambiguous, still somewhat romantic, phrasing does not acknowledge the hyponymous role of wilderness in relation to wildness. The implied hierarchy of the two concepts is still more or less dim and swerves more to the superordinate quality of wilderness, but in the final draft of the poem the tension gets resolved as the stress shifts toward the all-embracing diversity of wildness. Within the equilibrium of a sustainable environment, the continuity of "wilderness and weed" hinges on the participatory and prevailing fabric entailing "wildness and wet." Water upholds the intricate networks of global ecosystems as is marked by amorphous tendencies, "its liquidity and the principle of motion," which help it "instill [itself] into any given ecosystem" (Parnham 2010: 187). The darkened burn weaves its woollen coat along the rock-ribbed cage until it "low to the lake falls home" (Hopkins 2009: 153). This falling into home betokens the circular economy of ecosystems, wherein the banausic aridity of thoughtless selfism is confronted and dwarfed by the image of oikophilia defined by Roger Scruton as "the love and feeling for home" (2012: 3). This sense of love and feeling gives birth to the image of belonging and of being 
conscious that the natural world is not merely "mine and yours but ours" (227). The wildsome stream, sculpting the solid form of a ravine, is inhaled by the more tranquil tides of a lake. The wildness of the burn is thus transferred into the compassionate form of dwelling within the lake. It is kept as a silent abode where hopeful despair and despairing hope shine brightly and give light to "the nature of poetry as a letting-dwell" (Heidegger 2001: 213).

The second stanza unmasks the "turns and twindles" (Hopkins 2009: 153) of the burn and, as Parnham comments, intimates Hopkins' "knowledge of thermodynamic theory" (2010: 190), his warning that the heedless and venal disregard for nature would protract the entropic dispersal of energy "so pitchblack, fell-frówning, / It rounds and rounds Despair to drowning" (2009: 153). The drowning and henceforth drowned despair has no ear for hope and the Jesuit's words sound deafeningly comparable to the revelatory if apocalyptic conclusions put forward by Sir William Thomson in his seminal paper "On a Universal Tendency in Nature to the Dissipation of Mechanical Energy." In this paper, Thomson foregrounds and elaborates on an ominous vision of the universe which tends toward "the dissipation of mechanical energy" with the "restoration of it ... impossible in inanimate material processes," leading him to conclude that just as earth must have been uninhabitable within the finite framework of time past so it must hold true that within its finite future time framework the earth must remain "unfit for the habitation of man as at present constituted" (1857: 141-142). The grim prospect of energy, undergoing untrammelled dissipation presented in this fashion, may seem unredeemable, but the entropic processes can be subject to regulatory principles. Hopkins anticipates significant scientific findings by conjecturing nature's capacity to self-cure, which ultimately pivots on the efficient exchange of energy, for instance, between the atmosphere and our planet's surface. ${ }^{2}$

In the penultimate stanza, the apotheosis of "symbiotic" (Parnham 2010: 190) reciprocity is encountered in "the groins of the braes that the brook treads through" which are neither whipped nor deluged but "degged with dew, dappled with dew" (Hopkins 2009: 153). The baptismal dew droplets

${ }^{2}$ See Yan et al. 2016. The paper, published in Earth's Future, attempts to account for a less perceptive increase in the global mean surface temperatures (GMST), a phenomenon which has come to be referred to as "the Global Warming Hiatus," within the period of 1998-2013. Scientists have concluded that the major role for this to have occurred was played by the Atlantic and Southern Oceans which acted as a heat sink, the effect of which has been a more efficient redistribution of excessive atmospheric energy within the sea and hence atmosphere. 
of the meandering burn spray the steep banks, participating in the nurturing and sedimenting of the biodiversified riparian habitat composed "of wiry heathpacks, fitches of fern, / and the beadbonny ash" (153), while the braes inflate the nutritional and purifying value necessary for the thriving of the interlacing terrestrial and aquatic ecosystems within, beside, and along the stream bed, which can otherwise, in its narrow and rambunctious surge, declare itself to be a fairly life-flouting environment.

The last quatrain could be paraphrased into the question Hopkins posed on the principle of individuation: "Is not this pitch or whatever we call it then the same as Scotus's ecceitas?" (1959b: 151). The abbreviated form of baecceitas rendered by Hopkins as ecceitas is in all likelihood not an aimless wanderer, but, as indicated by Lichtmann, "a reminder of ecce, 'behold' or 'look'" (2014: 135). In contrast, Hopkins, in one of the letters to Robert Bridges, entreats his friend, who is about to ingest his new poetic rhythm, to "but take breath and read it with ears" (1955: 79), lest its singularity be dissolved. It is obvious then that to Hopkins the proper perception of a thing's thisness and the gracefully pitched scale of being guided towards the Sacred are contingent on seeing and its synesthetic union to hearing. 190 One who beholds and is devoid of the ability to hear is as incapacitated as one who hears but cannot behold even though it must be underscored that rather than pertaining only to the unimpaired physical ability, the act of beholding and the reception of sounds have as much if not more to do with the mind being permeable to the gathering impulses. Hopkins does not see as entirely deteriorated and spent the principle of individuation which clusters and "contracts the common nature (natura communis) to singularity" (Ingham and Dreyer 2004: 113). What is to remain after the brimful sources of wildness are spent and trampled is more of an open rather than a rhetorical question, and in accordance with this supposition a hope that the depletion of the individuating entity of wildness or its baecceitas has not yet come full circle remains not yet exhausted in its totality.

Should the disdain for natural processes continue and nature's ultimate wrath come to be, the individuality of man's being would just as swiftly rupture. Residing within the split separating the Creator from the created world, individuality is commensurate with free will intrinsically immersed in the stratum of alternatives within the created universe. The blessing of free will can be justified by a dutiful nourishment of cognition, the will's subordinate associate in exercising choice, which creates the paradigm where "freedom is compatible with necessity" (Hopkins 1955: 169). Free will is a plateau from which an individual can either choose to climb or retract from 
the heaven-craving wall of absolutes, the constrictions of which upon that individual are never altogether abolished. In its journey through life, free will, conveyed in its final form as choice, encounters a multiplicity of objects, and the presence of prudence in the intellect or its lack thereof defines the stateliness of one's moral character, whose corruption might induce the irredeemable severing of "the real relation between the creature and God" (Gardner 1948: 23) or between the creature and God's created world.

\section{IV}

On the gelid morning of 29 April, 1870, Hopkins saw "the ground in one corner of the garden full of small pieces of potsherd" upon which "long icicles carried on ... each like a forepitch of the shape of the piece of potsherd it grew on" (1959a: 201). An old lay brother, nearly half a century later, anecdotally confirmed that he had stumbled upon Hopkins awash in wonderment "crouching down that gate to stare at some wet sand. A fair natural 'e seemed to us, that Mr. 'opkins" (House and Storey 1959a: 408, editor's note). Whereas preternatural receptiveness to nature's inscape abounding boundlessly around Hopkins brought him cascades of joy, the stabs of sharp sorrow aroused at the defilement of that inscape invariably clawed away at his soul. It is plain enough that no inscape was too tiny for him not to merit unreserved appreciation. On 18 May in 1870, Hopkins, still a Jesuit novice, wrote in his journal: "I do not think I have ever seen anything more beautiful than the bluebell I have been looking at. I know the beauty of our Lord by it. It[s inscape] is [mixed of] strength and grace, like an ash [tree]" (1959a: 198). Less than three years later, then a student of philosophy at St. Mary's Hall, Stonyhurst, Hopkins felt a wave of ontological emptiness wash over him at witnessing the most gruesome of deeds as the ashtree - ignited by the pitch of grandeur he had seen in the bluebell with beauty surpassingly remindful of God - was despoiled of its inscape:

April 8 - The ashtree growing in the corner of the garden was felled. It was lopped first: I heard the sound and looking out and seeing it maimed there came at that moment a great pang and I wished to die and not to see the inscapes of the world destroyed any more. (230)

Hopkins' lamentation reverberates in "Beauty of Life," a lecture delivered by William Morris in 1880 to the Birmingham School of Art and 
School of Design and in which he condemns the "Century of Commerce" as guilty of the many trees, "magnificent cedars" in this particular instance, having been "wantonly murdered" in Hammersmith, West London, to make room "for the hideous dog-holes (forgive me!) which ... [had taken] their places" (1896: 102-103).

Diminishing the devastating consequences exerted by the inordinate amounts of greenhouse gas emissions riveted within the atmosphere, trees have an integral role in keeping our planet a cooler and less venomous place to live in. They purify air by devouring atmospheric pollutants and keep the levels of carbon dioxide and its heating effects from spiralling out of control by virtue of photosynthesis, a process during which the green plants utilize sunlight and its energy as a fuel to transform water entering the plant via its roots and carbon dioxide progressing to the deeper layers of a leaf through the tiny pores called stomata located in the lower epidermis into glucose and oxygen. Colin Tudge affirms that "the world has been getting warmer during the past 150 years" (2005: 370$)$, so that it can be fairly safe to assume that Hopkins must have felt and more so foreseen, particularly if we hypothesize that he had knowledge of photosynthesis and its impact, ${ }^{3}$ 192 some of the heavy damage that nature would sustain at the hands of heavy industrialism and the uncivil forms of urbanization. While trees are from an ecological perspective nature's progeny and benefactors, Hopkins also highly esteemed their aesthetic eminence. One could argue that the two categories are contained in one another as a testament of God's own beauty.

Nowhere is the disruption and desecration of nature's inscape more hauntingly communicated than in "Binsey Poplars," a dirge for the poplars felled in 1879, an event as harrowing as the razing down of the Stonyhurst ashtree whose axe-inflicted ruination had so powerfully impacted itself on Hopkins' heart and mind six years earlier. The haunting lines of the poem itself would suffice to paint the sense of desolation Hopkins was deluged with, yet that impression emerges even more pronounced when the poem is read in parallel to "Duns Scotus' Oxford." Both poems were first given sharper outlines in the late winter and finished in the early spring of 1879 ,

3 The Sun's interaction with plants was an unending source of fascination to Hopkins. See 22 Aug 1867: "Elm-leaves: - they shine much in the sun-bright green when near from underneath but higher up they look olive" (1959a: 152). 25 Sept 1869: "That autumn my eye was suddenly caught by the scaping of the leaves that grow in allies and avenues: I noticed it first in an elm and then in limes. They fall from the two sides of the branch or spray in two marked planes which meet at a right angle or more. This comes from the endeavour to catch the light on either side" (192). 
in this way coinciding chronologically with the completion of the first draft of "Inversnaid." The chronological agreement, however, extends to a deeply complementary thematic context. "Binsey Poplars" and "Duns Scotus' Oxford" foretell the fragility of the poetics of belonging that Hopkins would try to untie in working towards the final version of "Inversnaid." This attests to the fact that Hopkins was actively grappling and wrestling with the notions of ecopoetics so prophetic and enlightening for coming generations.

The opening verse of "Duns' Scotus Oxford" sheds light on the seemingly contending images of trees and towers, turning them into a harmonizing vision of the sylvan motifs as coexisting with the cultural and civic dimension of Oxford. The spires of Oxford, in unison with the towery trees breathing among and below the towers, gave the Oxford cityscape a distinctly couchant and all-encompassing mood. This image spurns the neo-classical ideal of the shepherd-poet marked by pastoral incorruptibility and remoteness from the social frames of existence. The strict binary of the natural and unnatural is in Hopkins' poetics is, as a rule, bereft of its prominence and becomes revamped in the oneness of home. Cuckoos, larks, and rooks waltzed around the branches which were shading the sun-baked pavements and imbued the "river rounded" (2009: 142) city with its leafy odour. The inhering inter-communion of "country and town" (142) swelled Hopkins' excitement which peaked upon realizing that "this air I gather and I release / He lived on" (142). This tells us that the Oxford of Hopkins' day still, but to a much smaller degree, shared the pre-industrial character of Scotus' Oxford. For Hopkins, Oxford embodied, both figuratively and literally, the essence of Scotus' teachings and, in keeping with this standard, Hopkins strove to develop his ecopoetics in the conflict of the here and there, which operates beyond mere geographical categories. While "here coped and poised powers" (142) laud nature as the unity of countryside and city, "a base and brackish skirt there" (142) incarnates the undoing of that once firmly held union that had, with the rise of suburbanization, started losing its resolve. This leads us across the bridge to investigate the destruction of that integrity of nature in "Binsey Poplars". The spreading ugliness which had "confounded / Rural rural keeping-folk, flocks, and flowers" (142) is mirrored in the unselving of the "sweet especial scene, / rural scene" (2009: 143). Aware that an adoration of wilderness is as perilous as morally unsupervised hacking at nature, Hopkins' evocation of rural innocence does not, as Parnham asserts, "exhibit preservationist elements" (2010: 209).

He was convinced that one's care for the here - wildness or, in a broader perspective, the Earth - could address the extraordinary complexities of 
the globe, but for this avenue of thought to remain fruitful, one should not lose sight of the delicate state of one's own immediate hearth and home. This echoes Cronon's exhortation that "we need to honor the Other within and the Other next door as much as we do the exotic Other that lives far away" (1996: 89). Nature contains the principles of self-preservation and destruction, and when the former, through misuse, become depleted, ruin must ensue. The extremely fraternally charged anguish that Hopkins felt facing elements conducive to the rotting of nature is expressed in the anxietyridden terms of how the "after-comers cannot guess the beauty been" (2009: 19). It only takes a dozen strikes to fracture the silence of ripe existence where the presencing of being unfolds and to send forth the hardship that drove even as imaginatively potent a poet as Hopkins to abstain from hoping and to write, in a letter to his friend Robert Bridges, that "the more I look the more black and deservedly black the future looks, so I will write no more" (1955: 28). Years later, Hopkins learned to trust that words can regain consonance with silence in the manner in which human and non-human life coincide, and it is this wholesome mode of natural being that we must, for our own sake, learn to embrace.

\section{WORKS CITED}

Bate, Jonathan. 2004. Fohn Clare: A Biography. London: Picador.

Bate, Jonathan. 2000. The Song of the Earth. London: Picador.

Clare, John. 1966. Clare: Selected Poems and Prose. Eds. Eric Robinson and Geoffrey Summerfield. London: Oxford University Press.

Cronon, William. 1996. "The Trouble with Wilderness or Getting Back to the Wrong Nature." In: Uncommon Ground: Rethinking the Human Place in Nature. Ed. by William Cronon. New York: W.W. Norton \& Co: 69-90.

Dickens, Charles. 1868. The Works of Charles Dickens: Sketches by Boz: Illustrative of Everyday Life and Every-day People. New York: Books, Inc.

Dyos, Harold James. 1982. "The Victorian City in Historical Perspective.” In: Exploring the Urban Past. Eds. David Cannadine and David Reeder. New York. Cambridge University Press: 3-18.

Gardner, W. H. 1948. "The Two Vocations.” In: Gerard Manley Hopkins: A Study of Poetic Idiosyncrasy in Relation to Poetic Tradition, Volume 1. London: Martin Secker \& Warburg: 1-37.

Heidegger, Martin. 2001. "Poetically Man Dwells." In: Poetry, Language, Thought. Trans. Albert Hofstadter. New York: Harper Perennial Modern Classics: 209-27.

Hobsbawm, Eric. 1975. The Age of Capital: 1848-1875. London: Weidenfeld \& Nicholson.

Hopkins, Gerard Manley. 1955. The Letters of Gerard Manley Hopkins to Robert Bridges. Ed. Claude Colleer Abbott. London: Oxford University Press. 
Hopkins, Gerard Manley. 1959a. The Fournals and Papers of Gerard Manley Hopkins. Eds. Humphry House and Graham Storey. London: Oxford University Press.

Hopkins, Gerard Manley. 1959b. The Sermons and Devotional Writings of Gerard Manley Hopkins. Ed. Christopher Devlin SJ, Oxford University Press.

Hopkins, Gerard Manley. 2009. The Major Works. Ed. Catherine Phillips. New York: Oxford University Press.

House, Humphry, and Graham Storey, eds. 1959a. "Notes to Journal." In: The fournals and Papers of Gerard Manley Hopkins. Eds. Humphry House and Graham Storey. London: Oxford University Press: 345-443.

Ingham, Mary Beth, and Mechthild Dreyer. 2004. The Philosophical Vision of Fohn Duns Scotus: An Introduction. Washington, D.C.: The Catholic University of America Press.

Lichtmann, Maria R. 2014. The Contemplative Poetry of Gerard Manley Hopkins. Princeton: Princeton University Press.

McEvoy, Arthur F. 1987. "Toward an Interactive Theory of Nature and Culture: Ecology, Production, and Cognition in the California Fishing Industry." In: Environmental Review: ER 11, 4: 289-305.

Morris, William. 1896. "Beauty of Life." In: Hopes and Fears for Art. London: Longman, Green, and Co.: 71-113.

Parnham, John. 2010. Green Man Hopkins: Poetry and the Victorian Ecological Imagination. Amsterdam: Rodopi.

Scruton, Roger. 2012. How to Think Seriously About the Planet: The Case for an Environmental Conservatism. New York: Oxford University Press.

Thompson, E. P. 1993. Customs in Common. London: Penguin Books.

Thomson, William. 1857. "On a Universal Tendency in Nature to the Dissipation of Mechanical Energy.” In: Proceedings of the Royal Society of Edinburgh, Volume 3. Edinburgh: The Society: 139-142.

Tudge, Colin. 2005. The Tree: A Natural History of What Trees Are, How They Live, and Why They Matter. New York: Crown Publishers.

White, Norman. 1992. Hopkins: A Literary Biography. New York: Clarendon Press.

Wordsworth, William. 2008. Selected Poetry. Eds. Stephen Gill and Duncan Wu. Oxford: Oxford University Press.

Yan, Xiao-Hai, et al. 2016. "The Global Warming Hiatus: Slowdown or Redistribution?" In: Earth's Future 4, 11: 472-482. 